\title{
Bioecology of Anastrepha alveata Stone (Diptera: Tephritidae) associated with wild plum fruits Ximenia americana L. (Olacaceae)
}

\author{
Almerinda Amélia Rodrigues Araújo ${ }^{1}$, Raimunda Nonata Santos Lemos ${ }^{2 *}$, José Ribamar Gusmão Araújo ${ }^{2}$, \\ Paulo Roberto Ramalho Silva ${ }^{3}$, Solange Maria França ${ }^{3}$, Clarice Diniz Alvarenga Corsato ${ }^{4}$, Janaína Marque \\ Mondego $^{2}$, Gislane da Silva Lopes ${ }^{2}$
}

\author{
${ }^{1}$ State Department of Education and Culture of Piauí (SEDUC), Teresina, PI, Brasil \\ ${ }^{2}$ State University of Maranhão (UEMA), São Luís, MA, Brasil \\ ${ }^{3}$ Federal University of Piauí (UFPI), Teresina, PI, Brasil \\ ${ }^{4}$ State University of Montes Claros (UNIMONTES), Janaúba, MG, Brasil
}

*Corresponding author: rlemos@cca.uema.br

\begin{abstract}
Fruit flies (Diptera: Tephritidae) are considered important pests of fruticulture due to considerable losses to production and limitation to free transit of fresh fruits. A generalist species is cresature that can live or feed on a wide variety of environemnts or host plants. Although, Anastrepha is a generalist species but infests a small range of plants. The specificity of this species with host plants is a peculiar characteristic of genus Anastrepha. Therefore, it is important to understand the host species and its feeding behaviour on host plants. This way, we will better know its ecology, biology and evolution for rational control ways and measures. Therefore, this study aimed at understanding the biology of Anastrepha alveata Stone (Diptera: Tephritidae). A study was carried out under controlled laboratory conditions $\left(27 \pm 2^{\circ} \mathrm{C}\right.$ temperature, $70 \pm 5 \% \mathrm{RH}$, photoperiod 12 hours) during the period from November/2015 to October/2017. Anastrepha alveata adults were obtained from wild plum fruits Ximenia americana L. (Olacaceae), collected from Savanna area in two fructification periods. One-hundred and fifty Anastrepha alveata adults were collected (60 females and 90 males) to determine sexual maturity, mating behavior, fecundity and longevity. The sexual maturity for Anastrepha alveata was 8-13 days after emergence for females. At this age they emitted signal of acceptance for mating and copulation. For males, 5-7 days after emergence this mating signals was given, which was characterized by the protrusion of the lateral abdominal pleural glands. The mating rhythm of Anastrepha alveata was crepuscular/nocturnal, beginning around 6 p.m. and extending to/after 9 p.m. Anastrepha alveata females did not mate with more than one male but mated more than once. The number of males did not affect significantly the mating time, the number of eggs and the longevity of Anastrepha alveata. The mean pupal period for Anastrepha alveata was 17.5 days. Two preferential peaks for adult emergence were observed at 10:00 am and 03:00 pm. The longevity of the adult insects was greater than 300 days, surviving until the fructification of its host (wild plum) in the following year. Therefore, $A$. alveata has a strictly monophagous food habit associated with the Ximenia americana host.
\end{abstract}

Keywords: Fruit flies, Maturity, Copulation, Fecundity, Longevity.

\section{Introduction}

Fruit flies (Diptera: Tephritidae) are insects that cause considerable damages to the fruit growing activity as consequence of injuries by the perforation of fruits for oviposition and larval development that occurs inside fruits. Anastrepha Schiner is the most diverse fruit fly genus in the American tropics and subtropics with more than 250 species described (Norrbom and Korytkowski, 2011; Norrbom et al., 2014). In Brazil, Anastrepha is currently represented by 120 registered species (Zucchi, 2008). According to Malavasi et al. (2000), Anastrepha species originate from American continent, where they are endemic. Most species of Anastrepha are distributed by the Neotropical region and some species occur in the south of the Neartic region. The genus is established in the southern United States, Mexico, Central America and throughout South America, where the species are distributed along a range between latitudes $35^{\circ}$ $\mathrm{N}$ to $35^{\circ} \mathrm{S}$, in a diversity of environments, from sea level up to altitudes of more than $3,000 \mathrm{~m}$, from areas of high rainfall to desert areas.

The species Anastrepha alveata Stone has been reported in Brazil, where its occurrences are associated with surveys using traps, where little is known and studied (Araujo et al., 2000; Martins et al., 2000; Alvarenga et al., 2010; Holanda, 2012), although being associated with Ximenia americana L. (Olacaceae) host in Mexico (Piedra et al., 1993; Sivinski et al., 1997). After a century of studies and surveys of fruit flies in Brazil, there was only one record of $A$. alveata in fruits, also sourced from wild plum $X$. americana (Araújo et al., 2014). Wild plum is naturally distributed in Africa, India, Central and South America. In Brazil, it is found in the northern, 
northeastern and midwestern regions with a wide distribution in several forest ecosystems (Sacande and Vautier, 2006). It is one of the main species of the Savanna biome shrub-tree extract (Fernandez and Bezerra, 1990). Fruits are characterized as a subglobular drupe of yelloworange color, pulp of firm consistency and bittersweet flavor, involving a single white almond, being a rich source of vitamin C and aromatic compounds (Brasileiro et al., 2008). The fructification period is annual and is concentrated between October and December, soon in the first rains. In all areas of its occurrence, wild plum is much researched due to its therapeutic activities based on popular knowledge, with emphasis on the discovery of new drugs (Brasileiro et al., 2008; Olabissi et al., 2011; Almeida et al., 2016).

In Brazil, there are few studies on biology and ecology for most species of fruit flies. In tropical and subtropical regions, the most studied species are those of economic importance, which are oligophagic/polyphagous. However, there are species that are highly specialized in certain hosts (Selivon, 2000). Anastrepha alveata can be inserted in this context, since it is associated only with wild plum and is considered rare and non-plague (Piedra et al., 1993; Aluja et al., 2014).

The studies on Anastrepha have focused on a combination of morphological, molecular, ecological and behavioral principles (Aluja, 1994). In this sense, the importance of knowing the biological and ecological behavior of monophagous species of tropical regions is evident, since they attack fruit of socioeconomic value for local communities. Therefore, this knowledge may serve to develop rational strategies for management of fruit flies. The aim of this work was to characterize the biological and behavioral aspects of mating, oviposition, fertility and survial of $A$. alveata, associated with $X$. americana wild plum.

\section{Results and discussion}

In total, 2744 fruits were collected from 17 locations in November-December/2015 and October-December/2016. About 2684 puparia were obtained from fruits, from which 1528 adults were emerged, being 766 males and 762 females, all of $A$. alveata species (Table 1 ). Due to the large number of adults obtained from fruits, we decided to carry out the evaluations from wild flies, since the breeding of this species was not established in laboratory. According to Aluja and Mangan (2008), wild flies should preferably be used, although most of the time, it is necessary to use laboratorycreated insects, since wild flies are not always available in enough amounts.

\section{Pupal period and emergence}

The mean pupal period was 17.5 days, with adult emergence peak at day 17, with 19 females and 20 males (Fig 1). For many species, the developmental period of the pupal stage is 16.4 days on average, varying according sex. Anastrepha fraterculus males usually emerge hours before females, presenting average development speed of 16.1 days, while in females, the average is 16.5 days (Da Cruz et al., 2000).

The pupal period of $A$. fraterculus was from 15 to 20 days at temperature of $25 \stackrel{\circ}{ }$ (Salles, 1995), making this species more adapted to regions of temperate climate, such as the Southeastern and Southern Brazil, where it has the status of primary pest for many fruit trees in these regions (Selivon, 2000).

It is part of the biological patterns and preferred time for adult emergence of Anastrepha species. We observed a greater number of emergences around $10 \mathrm{am}$ and $15 \mathrm{pm}$ hours for A. alveata females and, from 10 am and $13 \mathrm{pm}$ hours for males (Fig 2). For Aluja (1994), the period of the day for adult emergence usually occurs during the morning, as recorded in $A$. ludens (95.7\%) between 6:00 am and 10:00 am and in $A$. striata (62.3\%) between 9:00 am and 12:00 pm.

\section{Maturation and mating of A. alveata}

For the A. alveata maturation and mating characterization, the best events were observed in 10 cages of M2. The sexual maturation of females and acceptance of males for copulation was occurred at 8-13 days after emergence, with average around $10.4 \pm 0.63$ days. As for the sexual maturation of males, we observed that at 5-7 days (mean $5.8 \pm 0.24$ ) after emergence, they reached sexual maturity with sign of protrusion of the lateral abdominal pleural glands. According to Aluja et al. (1999), these structures are related to the production of sex pheromones. From then on, males began court, characterized by movements of the wings, as in an act of fanning/ventilating, and also performing anal touches on the walls of the cage. These behavioral patterns are associated with pheromone emission and are common to many Anastrepha species (Aluja, 1994; Aluja et al., 1999).

The time difference for sexual maturation has shown that males are more precocious and females demand more time to reach sexual maturation. In addition, females need to ingest a greater variety of nutrients, mainly protein substances, essential for sexual maturation (Bateman, 1972) and consequently of eggs.

In breeding cages, other events were observed, in which sexually mature males tried to mate with other males, but separating quickly, or other males overlapping a male in copulation with a female, forming a stacking up to three overlapped males. According to Aluja et al. (1999), during peak hours of mating activity, males try to mate with other males, suggesting that there is no early discrimination by males of potential females (mature females) for mating.

A description of the bioecology of $A$. fraterculus (Wiedemann) reports that males become reproductive before females, requiring about five days for males and seven days for females to reach reproductive stage (Salles, 1995). However, Aluja et al. (1999) reported the sexual maturation for females of some species, such as $A$. obliqua (Macquart) (10-12 days), $A$. serpentina (Wiedemann) and $A$. suspensa (Loew) (14 days), A. striata (Schiner) (14-15 days), A. fraterculus (17 days), A. pseudoparallela (Loew) (18 days), A. sororcula Zucchi (24 days) and A. bistrigata Bezzi (26 days). Comparing with these data, the age of sexual maturation of $A$. alveata is closer to that of $A$. obliqua. Da Cruz et al. (2000), in a review on the biology and development of fruit flies, found that under natural conditions, the reproductive potential of $A$. obliqua females occurs from six days of age. Due to the aforementioned similarity between $A$. alveata and $A$. obliqua, it is presumed that this age for $A$. alveata is not different, even because the short fructification period of its host is determinant to accelerate the reproductive behavior of the species. 
Table 1. The Ximenia americana fruits collected and Anastrepha alveata adults obtained from Palmeiras home garden, municipality of São Pedro of Piauí, PI (November-December/2015 and October-December/2016).

\begin{tabular}{|c|c|c|c|c|c|c|c|}
\hline \multirow{2}{*}{ Year } & \multirow{2}{*}{ Collection periods } & \multirow{2}{*}{$\begin{array}{l}\text { Number of } \\
\text { collections }\end{array}$} & \multirow{2}{*}{$\begin{array}{l}\text { Number of } \\
\text { fruits }\end{array}$} & \multirow{2}{*}{ Puparia } & \multicolumn{3}{|c|}{ Anastrepha alveata } \\
\hline & & & & & 우 & $\hat{0}$ & Total \\
\hline 2015 & $11 / 08$ to $12 / 21$ & 7 & 1177 & 933 & 371 & 372 & 743 \\
\hline 2016 & $10 / 14$ to $12 / 19$ & 10 & 1567 & 1751 & 391 & 394 & 785 \\
\hline Total & & 17 & 2744 & 2684 & 762 & 766 & 1.528 \\
\hline
\end{tabular}

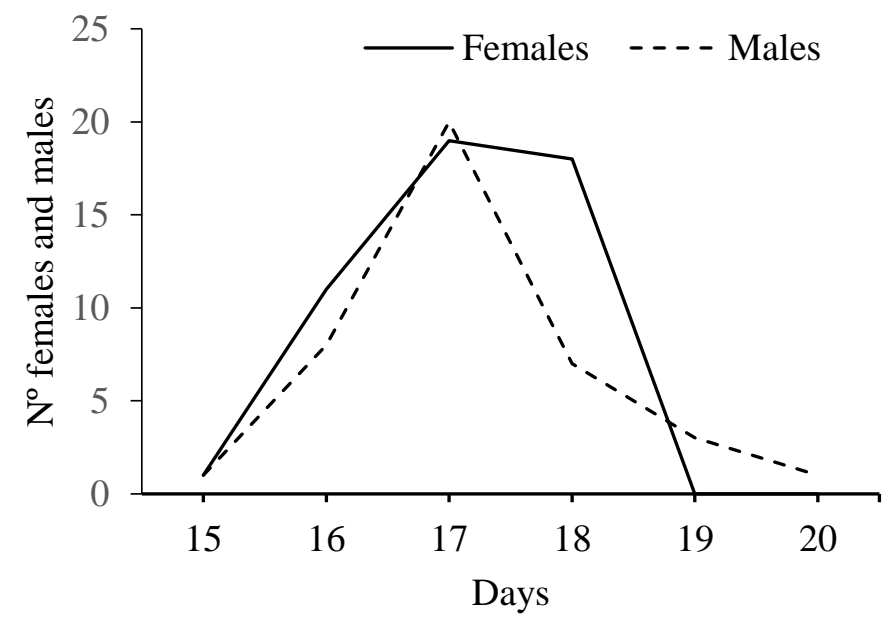

Fig 1. Period (in days) for the development of pupal stage of Anastrepha alveata under controlled conditions (temperature $27 \pm 2$ oC and $\mathrm{RH} 70 \pm 5 \%)$.

Table 2. Mating time (minutes), fecundity (number of eggs) and longevity (days) of Anastrepha alveata females when kept with one or two Males/female under controlled conditions (temperature $27 \pm 2{ }^{\circ} \mathrm{C}, \mathrm{RH} 70 \pm 5 \%$ and photoperiod of 12 hours).

\begin{tabular}{l|l|l}
\hline Parameters evaluated & M1 (1 male/female) & M2 (2 males/female) ${ }^{1}$ \\
\hline Mating time (minutes) & $81.3 \pm 19.42$ & $118.4 \pm 8.14$ \\
Fecundity (number of eggs) & $79.0 \pm 34.08$ & $193.3 \pm 63.04$ \\
Longevity (days) & $170.7 \pm 15.90$ & $162.7 \pm 21.06$ \\
\hline
\end{tabular}

${ }^{1}$ There was no significant difference at $5 \%$ probability by the $t$ test.

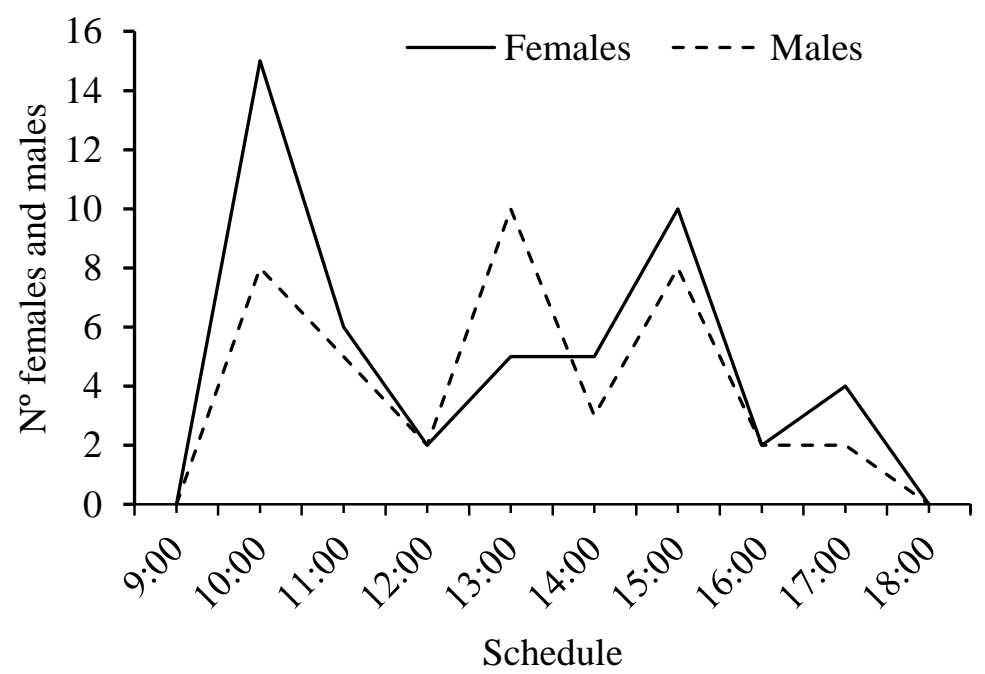

Fig 2. Emergence peak time for Anastrepha alveata under controlled conditions (temperature $27 \pm 2{ }^{\circ} \mathrm{C}$ and $\mathrm{RH} 70 \pm 5 \%$ and 12 hour photoperiod). 
There was a low mating percentage (25\%), since out of $60 \mathrm{~A}$. alveata females exposed to males only 15 mated. The number of males per female presented a positive correlation, but not significant with the mating length ( $r=$ $0.40, P=0.12$ ) and with the number of eggs (fecundity) ( $r=$ $0.41, P=0.17$ ). However, there was a negative and nonsignificant correlation with longevity $(r=-0.08, P=0.78)$. Longevity had a negative correlation with the number of eggs deposited by $A$. alveata, and this correlation was not significant ( $r=-0.44, P=0.15$ ) (Table 2). Therefore, these results indicate that the number of males that females was exposed to did not interfere with mating length, fecundity and longevity. Therefore, regardless of number of males, females must have individual peculiarities within the species that determine their reproductive performance.

Anastrepha alveata revealed a daily crepuscular/nocturnal mating rhythm, starting at about 6:00 pm, extending until after 9:00 pm. This time for the beginning of mating activities was recorded for $\mathrm{M} 1$ and $\mathrm{M} 2$ treatments. In the case of breeding cages, where population density was high, copulation stared a little earlier and probably the competition of many males searching for mating is an inducing factor for this event. The mean copulation length ranged from $81.3 \pm 19.42$ minutes for $\mathrm{M} 1$ ( 1 male and 1 female) and $118.4 \pm 8.14$ minutes for M2 ( 2 males and 1 female) (Table 2).

The mating time probably follows species-specific patterns, $A$. robusta (Greene) and $A$. fraterculus, in which copulation is observed early in the morning, for other species such as $A$. ludens (Loew), A. grandis (Macquart) and $A$. pseudoparallela, mating activities are restricted to late afternoon (Aluja, 1994; Salles, 1995), i.e., crepuscular, as observed for A. alveata.

No copulation repetition was recorded when one female was submitted to two males (M2). Thus, it was not possible to determine if the female copulated with more than one partner. In the case where only one male was kept with one female (M1), more than one mating was recorded for some couples. Similarly, $A$. fraterculus, $A$. sororcula and $A$. pseudoparallela rarely mated more than once and never more than three times (Aluja et al., 1999). It is noteworthy that $A$. ludens mates at dusk, lasting from 20 minutes to 3 hours, and that couples kept in cages mated repeatedly at intervals throughout their lives (Díaz-Fleischer and Aluja, 1999).

Anastrepha alveata presented mean fecundity of $79 \pm 34.08$ for M1 and $193.3 \pm 63.04$ for M2 (Table 2), but did not characterize a defined pattern, since females with loads of 18 (M1) and 507 (M2) eggs during life were observed (125 and 96 days, respectively). The longest lived female (M1) (237 days) was less fecund (78 eggs) than the shortest lived female (M2) (92 days), which produced 147 eggs. According to a study carried out in laboratory, in $A$. fraterculus the maximum number of eggs deposited per female was 612 , with mean of around 400 eggs (Salles, 1995).

\section{Longevity of A. alveata associated with fructification of $X$. Americana}

Mean longevity of $329.5 \pm 22.50$ days was recorded for males and $308.5 \pm 4.50$ days for females, with the longest lived male surviving 352 days and female 313 days. Aluja et al. (1999) found 431 days of longevity for an A. alveata male kept under laboratory conditions. Based on data obtained, it was verified that the longevity of $A$. alveata is sufficient to reach the new fructification period of its natural host, since wild plum begins to flower (floral buds) in July with fruit ripening in October to November. This characterizes that $A$. alveata presents longevity adapted to the phenology of its specific host. This suggests that the species has special survival mechanisms, which is not diapause, since it was kept in daily activities in the breeding cages. Diapause is a biological strategy, allowing fruit flies to survive long periods, when host fruits are scarce or unavailable but has never been documented for Anastrepha (Aluja et al., 1999; Aluja et al., 1998). However, for many species of other tephritid genera such as Carpomya, Rhagoletis and Zonosemata, diapause has already been proven (Prokopy and Papaj, 1999).

The results obtained in this research bring information about A. alveata, a tephritid of tropical climate, presenting univoltine reproductive behavior and monophagous food habit, whose life cycle and longevity are closely related to the phenology of its host, the wild plum tree $X$. Americana. As everything in nature has its value in the life sustainability, the $A$. alveata host has aroused the interest of pharmacological research due to the therapeutic importance that has been presented in the treatment of various diseases and its use in rural communities as phytotherapeutic resources against inflammation and healing, in addition to the use of fruits as food. However, further studies should be carried out for a better understanding of the rational control of a Neotropical monophagous Anastrepha species.

\section{Materials and methods}

\section{Fruit collections to obtain A. alveata specimens}

The collection of wild plum fruits were carried out at Palmeiras home garden, municipality of São Pedro do Piauí $\mathrm{PI}, 106 \mathrm{~km}$ from state capital Teresina (05955'46 "S and 42ㄴㄱ' $07^{\prime \prime}$ W), at altitude of $264 \mathrm{~m}$ a.s.l., Savanna biome with stretches of coconut forest (CEPRO, 2011). At the fructification season of wild plum, from October to December, samples of ripe fruits (freshly fallen fruits or in the plant) were weekly collected. Fruits were transported in plastic trays to the Laboratory of Entomology, Center of Agricultural Sciences (CCA) - Federal University of Piauí (UFPI), Teresina-PI.

Sampled fruits were counted and distributed in plastic trays $(40 \times 25 \times 7 \mathrm{~cm})$ containing a layer of sieved and autoclaved sand to provide pupation substrate. Puparia were sieved and packed in plastic containers $(250 \mathrm{~mL})$ with wet sand, covered with voile fabric and kept in the adult rearing room under controlled conditions (temperature $27 \pm 2^{\circ} \mathrm{C}$, air $70 \pm 5 \% \mathrm{RH}$ and photoperiod of $12 \mathrm{~h}$ ).

\section{Anastrepha alveata breeding}

Emerged adults were transferred to breeding cages where they were kept and fed and observed daily for six months. After this period, insects were kept providing food and water and dead flies were removed. The diet was supplied in Petri dish $(60 \times 15 \mathrm{~mm})$ and was composed of a mixture of hydrolyzed protein (Bionis), sterilized raw wheat germ (Walmon) and granulated sugar at the ratio of 1: 1 : 3 , 
refined in blender. Water was supplied by capillarity through a hydrophilic cotton yarn inserted in the top of a closed plastic container $(100 \mathrm{~mL})$. Breeding cages were manufactured in acrylic $(50 \mathrm{~cm}$ height, $35 \mathrm{~cm}$ length and 30 $\mathrm{cm}$ width), with top and sides perforated with $2 \mathrm{~mm}$ holes. The anterior face with a circular opening ( $15 \mathrm{~cm}$ in diameter) was closed with voile fabric (a "long sleeve" type $80 \mathrm{~cm}$ in length), which allowed accessing the interior of the cage. The posterior face was closed with an oviposition screen (voile fabric with the inner face covered by a thin film of silicone - "RTV Maintenance Silicone, Acetic Cure"). As adults died, they were removed and females kept in $70 \%$ ethanol for confirmation of the $A$. alveata species, using the keys of Steyskal (1977) and Uramoto (2007). Voucher specimens were preserved in $70 \%$ ethanol and deposited in the collection of Entomology Laboratorie/Department of Plant Protection of UFPI, Campus "Petrônio Portela", Teresina, PI and in the Collection "Iraci Paiva Coelho" from State University of Maranhão (UEMA), Campus "Cidade Universitária Paulo VI", São Luís, MA.

Adults obtained from fruits were used for longevity, mating and fecundity evaluations. The pupal period of $A$. alveata was also evaluated.

\section{Pupal period}

Larvae (pre-pupae) were extracted from wild plum fruits and individualized in plastic containers $(50 \mathrm{~mL})$ with sand substrate (autoclaved and moist) and covered with voile fabric. Pupae were obtained from four fruit collections (year 2016), and 40 pupae per collection were used for observation.

\section{Longevity}

Longevity referred as period between adult emergence and death (in days). For this, adults of the same age were grouped in breeding cages that were daily supervised for the removal of dead flies. Two A. alveata generations of wild flies were developed (Nov./2015 to Oct./ 2016 and Nov./2016 to Oct./2017).

\section{Performance of A. alveata female (mating, fecundity and longevity)}

To determine sexual maturation (male and female), copulation time and length, number of copulations, copulation with more than one male, fecundity and longevity, 150 newly emerged insects were selected, including 60 females and 90 males. Insects were placed in plastic cages (transparent plastic containers with $9.5 \mathrm{~cm}$ in height $\times 12 \mathrm{~cm}$ in bottom diameter $\times 14 \mathrm{~cm}$ in top diameter, $1 \mathrm{~L}$ capacity, containing holes on the surface). A female and one or two males were kept in each cage. The number of males in the cages was considered as different treatments, assigned and named as M1 (proportion of 1 male to 1 female) and M2 (proportion of 2 males to 1 female). Each treatment was repeated 30 times. In treatments containing two males, one of them was marked in the mesoscutum with white paint (male-1 no mark / male-2 with mark), used to mark bees (uniPOSCA - China). Preliminary observations in breeding cages revealed that males started approaching at around 5:00 p.m. and from then on, insects were observed during the first four hours of scotophase for a period of 18 days. This was conducted to evaluate the age of sexual maturation (days of the first copulation after emergence), time, length (in minutes) and number of copulations (counting from the effective observation of couple's union up to separation; daily observation for the observation of mating couples, first copulation or repetition). To estimate fecundity, eggs were removed from the cage (every 3 days) with a soft humidified hair brush, the time from posture to female's death. Longevity was evaluated in days from emergence to female's death.

\section{Statistical analysis}

Mating length (minutes), fecundity (number of eggs) and longevity (days) were submitted to analysis of variance (ANOVA) and means were compared by t-test $15 \%$ probability). The correlation between number of males per female ( 1 male/female and 2 males/females) on the mating length (minutes), number of eggs (fecundity) and longevity (days) of A. alveata was calculated using the Pearson's correlation coefficient and the SAS Institute software.

\section{Conclusion}

The mean pupal period for A. alveata was 17.5 days. Two preferential peaks for adult emergence were observed at 10:00 am and 03:00 pm. The longevity of the adult insects was greater than 300 days, surviving until the fructification of its host, wild plum, in the following year. Therefore, $A$. alveata showed a strictly monophagous food habit associated with the Ximenia americana host.

\section{Acknowledgements}

We thank to the State Department of Education and Culture of Piauí, SEDUC-PI, for the granting of the first author's leave for the postgraduate course (Doctorate) and the Federal University of Piauí, UFPI, for the support of this research. To FAPEMA - Foundation for Research and Scientific and Technological Development Support of Maranhão for financial support (PROCESS: CBIOMA-02946/12).

\section{References}

Almeida MLB, Souza Freitas WE, Morais PLD, Sarmento JDA, Alves RE (2016) Bioactive compounds and antioxidant potential fruit of Ximenia americana L. Food Chem. 192: 1078-1082.

Aluja M (1994) Bionomics and management of Anastrepha. Annu Rev Entomol. 39: 155-178.

Aluja M, Mangan RL (2008) Fruit fly (Diptera: Tephritidae) host status determination: critical conceptual, methodological, and regulatory considerations. Annu Rev Entomol. 53: 473-502.

Aluja M, López M, Sivinski J (1998) Ecological evidence for diapause in four native and one exotic species of larvalpupal fruit fly (Diptera: Tephritidae) parasitoids tropical environments. Ann Entomol Soc America. 91(6): 821-833.

Aluja M, Piñero J, Jácome I, Díaz-Fleischer F, Sivinski J (1999) Behavior of flies in the genus Anastrepha (Trypetinae: Toxotrypanini). In: Aluja M, Norrbom AL (eds) Fruit Flies 
(Diptera: Tephritidae): phylogeny and evolution of behavior. New York, CRC Press.

Aluja M, Sivinski J, Van Driesche R, Anzures-Dadda A, Guillén $L$ (2014) Pest management through tropical tree conservation. Biodivers Conserv. 23(4): 831-853.

Alvarenga CD, Alves DA, Silva MS, Lopes EN, Novais Lopes GN (2010) Moscas-das-frutas (Diptera: Tephritidae) em pomares da área urbana no norte de Minas Gerais. Rev Caatinga. 23(2): 25-31.

Araujo EL, Lima FA, Zucchi RA (2000) Rio Grande do Norte. In: Malavasi A, Zucchi RA (eds) Moscas-das-frutas de Importância econômica no Brasil: conhecimento básico e aplicado. Ribeirão Preto, Holos Editora.

Araújo AAR, Silva PRR, Querino RB, Silva EPS, Soares LL (2014) Moscas-das-frutas (Diptera: Tephritidae) associadas às frutíferas nativas de Spondias spp. (Anacardiaceae) e Ximenia americana L. (Olacaceae) e seus parasitoides no estado do Piauí, Brasil. Semin Cienc Agrar. 35(4): 17391750.

Bateman MA (1972) The ecology of fruit flies. Annu Rev Entomol. 17: 493-518.

Brasileiro MT, Egito AA, Lima JR, Randau KP, Pereira GC, Neto PJR (2008) Ximenia americana L.: botânica, química e farmacologia no interesse da tecnologia farmacêutica. Rev Bras Farm. 89(2): 164-167.

CEPRO - Fundação Centro de Pesquisas Econômicas e Sociais do Piauí (2011). Available in: http://www.cepro.pi.gov.br/download/201106/CEPR21 5 4d89dde55.pdf. Accessed in Feb 06, 2017.

Da Cruz IBM, Nascimento JC, Taufer M, Oliveira AK (2000) Morfologia do aparelho reprodutor e biologia do desenvolvimento. In: Malavasi A, Zucchi RA (eds) Moscasdas frutas de Importância econômica no Brasil: conhecimento básico e aplicado. Ribeirão Preto, Holos Editora.

Díaz-Fleischer F, Aluja M (1999) Behavior of tephritid flies: a historical perspective. In: Aluja M, Norrbom A (eds) Fruit flies (Diptera: Tephritidae): phylogeny and evolution of behavior. New York, CRC Press.

Fernandes A, Bezerra P (1990) Estudo fitogeográfico do Brasil. Fortaleza, Stylus comunicações.

Holanda MJA (2012) Diversidade de espécies de Anastrepha Schiner, 1868 (Diptera: Tephritidae) no município de Caxias e no Parque Estadual do Mirador, Maranhão, Brasil. Master Dissertation. National Research Institute of the Amazon, University of Amazonas Foundation, Manaus, Brazil.

Malavasi A, Zucchi RA, Sugayama, RL (2000) Biogeografia. In: Malavasi A, Zucchi RA (eds) Moscas-das-frutas de importância econômica no Brasil: conhecimento básico e aplicado. Ribeirão Preto: Holos Editora.
Martins DS, Uramoto K, Malavasi A (2000) Espírito Santo. In: Malavasi A, Zucchi RA (eds) Moscas-das-frutas de importância econômica no Brasil: conhecimento básico e aplicado. Ribeirão Preto, Holos Editora.

Norrbom AL, Castillo-Meza AL, García-Chávez H, Aluja M, Rull J (2011) A new species of Anastrepha (Diptera: Tephritidae) from Euphorbia tehuacana (Euphorbiaceae) in Mexico. Zootaxa 3780: 567- 576.

Norrbom AL, Korytkowski CA (2011) New species of and taxonomic notes on Anastrepha (Diptera: Tephritidae). Zootaxa 2740: 1-23. Available in:

$<$ https://www.researchgate.net/profile/Allen Norrbom/pub lication/228835154/>Accessed in Jan 03, 2017.

Olabissi OAF, Moussa O, Moustapha O, Edgard ZF, Marius L, Pierre GI (2011) Acute toxicity and anti-inflammatory activity of aqueous ethanol extract of root bark of Ximenia americana L. (Olacaceae). Afr J Pharm Pharmacol. 5(7): 806-811.

Piedra E, Zuniga A, Aluja M (1993) New host plant and parasitoid record in Mexico for Anastrepha alveata Stone (Diptera: Tephritidae). Proc Entomol Soc Wash, USA.

Procopy RJ, Papaj DR (1999) Behavior of flies of the genera: Rhagoletis, Zonosemata, and Carpomya (Trypetinae: Carpomyina). In: Aluja M, Norrbom AL. (eds) Fruit flies (Diptera: Tephritidae): phylogeny and evolution of behavior. New York, CRC Press.

Sacande M, Vautier H (2006) Ximenia americana L. Seed Leaflet 112: 1-2.

Salles LAB (1995) Bioecologia e controle da mosca-das-frutas sul-americana. Pelotas: EMBRAPA-CPACT.

Selivon D (2000) Relações com as plantas hospedeiras. In: Malavasi A, Zucchi RA (eds) Moscas-das-frutas de importância econômica no Brasil: conhecimento básico e aplicado. Ribeirão Preto, Holos Editora.

Sivinski J, Aluja M, Lopez M (1997) Spatial distributions of parasitoids of Mexican Anastrepha species (Diptera: Tephritidae) within the canopies of fruit trees. Ann Entomol Soc Am. 90: 604-618.

Steyskal GC (1977) Pictorial key to species of the genus Anastrepha (Diptera: Tephritidae). Washington, The Entomological Society of Washington.

Uramoto OK (2007) Diversidade de moscas-das-frutas (Diptera, Tephritidae) em pomares comerciais de papaia e em áreas remanescentes da Mata Atlântica e suas plantas hospedeiras nativas, no município de Linhares, Espírito Santo. Doctoral Thesis. University of São Paulo, Agriculture School Luiz de Queiroz, ESALQ/USP, Piracicaba, Brazil.

Zucchi RA (2008) Fruit flies in Brazil - Anastrepha species their host plants and parasitoids. Available in: www.lea.esalq.usp.br/anastrepha/. Accessed in: Mar 10, 2018. 